\title{
PENGARUH APLIKASI KOMPOS JERAMI PADI+PANGKASAN TITHONIA DAN BIOCHAR SEKAM PADI TERHADAP SERAPAN NITROGEN, FOSFOR, DAN KALIUM SERTA PRODUKSI PADI METODE SRI (SYSTEM OF RICE INTENSIFICATION) DI KOTA PADANG
}

\author{
Effect of Application of Rice Straw + Tithonia Pruning Compost and \\ Rice Husk Biochar on Nitrogen, Phosphorus, and Potassium Uptake \\ and Rice Production of SRI (System of Rice Intensification) Method \\ in Padang City
}

\author{
Erick Yuhardi ${ }^{*}$, Gusnidar, Syafrimen Yasin \\ Program Studi Ilmu Tanah, Fakultas Pertanian Universitas Andalas Limau Manis Padang 25175 \\ *Penulis korespondensi: yuhardyerick@gmail.com
}

\begin{abstract}
A study that was aimed to examine the effect of rice straw + tithonia pruning compost and rice husk biochar application on N, P and K uptake and rice production of SRI (System of Rice Intensification) method, was carried out from November 2019 - February 2020 in Kuranji District, Padang City, West Sumatra. This study used a randomized block design consisting of 6 treatments and 3 replications. The treatments were $\mathrm{A}=$ control, $\mathrm{B}=100 \% \mathrm{~K}$ (compost), $\mathrm{C}=75 \% \mathrm{~K}+25 \% \mathrm{~B}$ (biochar), $\mathrm{D}=50 \%$ $\mathrm{K}+50 \% \mathrm{~B}, \mathrm{E}=25 \% \mathrm{~K}+75 \% \mathrm{~B}$, and $\mathrm{F}=100 \% \mathrm{~B}$. The results showed that there was an increase of N, P and K uptake by rice with the application of $25 \%$ compost $+75 \%$ biochar. The treatment increased plant height, total tiller number and grain weight by $30 \mathrm{~cm}, 25.34$ stems and $5.47 \mathrm{t} \mathrm{ha}^{-1}$, respectively higher than that in control.
\end{abstract}

Keywords: biochar, compost, NPK, SRI

\section{Pendahuluan}

Upaya mendukung pembangunan pertanian telah banyak dilakukan oleh pemerintah maupun lembaga-lembaga non pemerintah. Berbagai inovasi telah berkembang dan dihasilkan untuk mendukung perubahan dalam proses pembangunan pertanian ke arah yang lebih baik . Beberapa program perubahan pertanian telah berhasil diimplementasikan dan diterima oleh sebagian petani di beberapa wilayah. Akan tetapi juga ada inovasi tersebut belum dapat langsung diterapkan oleh petani dan masih perlu waktu yang cukup lama agar inovasi tersebut dapat diaplikasikan petani sebagai pengguna. Salah satu inovasi tersebut ialah budidaya padi dengan metode SRI (System of Rice Intensification). Menurut Randriamiharisoa (2002) metode ini diterapkan dengan prinsip memperbaiki perakaran padi dengan cara pengaturan pengairan, menerapkan tanam tunggal pada praktik tanam, waktu tanam dini, dan memperbaiki kualitas tanah.

Metode tanam cara SRI dapat mengurangi jumlah penggunaan air dan kebutuhan benih. Metode ini juga dikenal dengan tanam padi sebatang dengan produksi gabah dapat mencapai 8-8,5 ton per hektare yang diperkenalkan oleh Universitas Andalas (Kompas, 2008). Pada dasarnya proses pengolahan tanah yang dilakukan petani padi organik SRI hampir sama dengan pengolahan tanah yang dilakukan oleh petani padi konvensional. Beberapa kegiatan pengolahan 


\section{Jurnal Tanah dan Sumberdaya Lahan Vol 8 No 1: 301-308, 2021 e-ISSN:2549-9793, doi: 10.21776/ub.jts1.2021.008.1.33}

tanah yang dilakukan adalah pembajakan, pembuatan saluran air, perataan tanah dan babad galeng pematang. Pembibitan (penyemaian benih) memerlukan waktu yang berbeda. Bibit yang ditanam pada budidaya padi metode SRI berumur 7-14 hari setelah semai sedangkan untuk budidaya padi konvensional umur padi yang ditanam yaitu 20-22 hari setelah tanam (HST). Bibit pada umur ini telah memiliki dua helai daun atau lebih tinggi \pm 10 $15 \mathrm{~cm}$ sehingga bibit perlu diperlakukan secara hati-hati terutama pada bagian akar agar tidak rusak dicabut dari persemaian. Benih muda pada metode SRI ini diharapkan dapat menumbuhkan tunas lebih awal dan akan banyaknya pertumbuhan tunas primer sebagai tunas yang lebih produktif serta lebih cepat pembentukannya. Penyebaran metode tanam padi sebatang juga dilakukan oleh Politeknik Pertanian di Payakumbuh melalui penyuluhan dan pembuatan demplot SRI (tanam padi sebatang) pada Kelompok Tani Sawah Bandang, Kenagarian Koto Tuo, Kecamatan Harau Kabupaten Lima Puluh Kota, dengan hasil 8 ton per hektare, sementara dengan tanam padi secara konvensional hasilnya hanya 4 ton per hektare (Djinis et al., 2008).

Menurut Badan Pusat Statistik (2017) produksi padi di Sumatera Barat pada tahun 2016 tercatat sebesar 2.503.452 ton. Angka tersebut turun sebesar 1,85 persen dibandingkan produksi padi tahun 2015 yaitu sebesar 2.550.609 ton. Di Kota Padang khususnya produksi padi pada tahun 2016 juga mengalami penurunan dari tahun 2015 yaitu sebesar 88.573 ton ke 82.620 ton. Penurunan produksi tersebut salah satunya diakibatkan oleh tidak seimbangnya input yang diberikan ke tanah serta tanpa adanya pengembalian atau penambahan bahan organik ke dalam tanah. Lahan sawah Penelitian di kecamatan Kuranji mempunyai tingkat kesuburan tanah yang sangat rendah karena ketersediaan terutama unsur hara makro $(\mathrm{N}, \mathrm{P}$, dan $\mathrm{K})$ di dalam tanah berkisar sangat rendah sampai rendah. Hasil analisis awal kimia lahan sawah menunjukkan bahwa pH 5,41 masam; N-total 0,21\% sedang; P-tersedia 5,95 ppm rendah dan K-dd 0,22 cmol $\mathrm{kg}^{-1}$ rendah. Oleh sebab itu perlu dilakukan penambahan pupuk terutama pupuk organik (PO) ke dalam tanah. PO adalah pupuk yang berasal dari bahan organik dan biasanya diberikan melalui tanah, seperti jerami padi. Feng et al. (2017) menyatakan bahwa jerami padi mengandung C-organik (50,36\%), N (0,87\%), P $(0,45 \%), \mathrm{K}(2,04 \%), \mathrm{pH}(6,93 \%)$. Berdasarkan penelitian Prasetiya et al., (2015) pemakaian kompos jerami yang konsisten dalam jangka panjang dapat meningkatkan kandungan bahan organik tanah dan mengembalikan kesuburan tanah.

Bahan organik yang mempunyai kriteria yang mudah melapuk dan mempunyai hara yang tinggi adalah tithonia. Pangkasan Tithonia mempunyai kandungan nitrogen $(\mathrm{N})$ yang tinggi $(>3 \%)$ dan kadar lignin yang rendah, serta $\mathrm{C} / \mathrm{N}$ yang rendah sehingga mudah melapuk (Jama et al., 2000; Gusnidar, 2007). Jerami padi sulit mengalami proses dekomposisi (melapuk) karena mempunyai kandungan lignin yang tinggi, oleh karena itu dengan penggabungan antara jerami padi dan pangkasan tithonia sebagai kompos akan mempercepat pelapukan pada jerami padi. Campuran kedua bahan ini (1:1) yang dikomposkan diyakini mampu memperbaiki ketersediaan hara beberapa jenis lahan sub optimal, seperti Oxisol, Inceptisol, Regosol (Gusnidar et al, 2011; Gusnidar et al, 2017). Gusnidar et al., (2019) menyatakan bahan input kompos asal pangkasan tithonia dan jerami padi (1:1) dalam memperbaiki ciri kimia Ultisol, serta bobot kering jerami, bobot kering biji dan bobot 100 biji yang optimal diperoleh pada dosis 7.50 ton ha-1. Selanjutnya Gusnidar et al., (2008) menyatakan bahwa pemakaian kompos jerami padi plus tithonia $(50 \%+50 \%)$ dengan takaran $5 \mathrm{t} \mathrm{ha}^{-1}$ mampu memperbaiki sifat dan ciri kimia pada tanah sawah intensifikasi dan menghemat pupuk buatan sebanyak $50 \%$.

Biochar merupakan langkah lain dalam memperbaiki produktivitas tanah (Lehmann dan Joseph, 2009) yang berasal dari proses pemanasan biomassa pada keadaan oksigen terbatas atau tanpa oksigen. Aplikasi biochar ke lahan pertanian (lahan kering dan basah) dapat meningkatkan kemampuan tanah menyimpan air dan hara, memperbaiki kegemburan tanah dan mengurangi penguapan air dari tanah. Pemilihan bahan baku biochar ini didasarkan pada produksi sisa tanaman yang melimpah dan belum termanfaatkan seperti sekam padi. Sekam 


\section{Jurnal Tanah dan Sumberdaya Lahan Vol 8 No 1: 301-308, 2021 e-ISSN:2549-9793, doi: 10.21776/ub.jts1.2021.008.1.33}

sebagai limbah penggilingan padi jumlahnya mencapai 20-23\% dari gabah. Yasin (2017) melaporkan pemberian bahan organik berupa pupuk kompos dan biochar pada formulasi $25 \%$ kompos $+75 \%$ biochar mampu memperbaiki sifat kimia Inceptisol seperti $\mathrm{N}$ total $0,16 \%$, C-organik 3,55\%, P-tersedia 6,15 ppm, K-dd 0,15 me $100 \mathrm{~g}^{-1}$ dan KTK 7,39 me $100 \mathrm{~g}^{-1}$. Hasil penelitian sebelumnya belum melaporkan bagaimana peranan kompos jerami plus tithonia yang dicampur dengan biochar sekam pada lahan basah. Diharapkan dengan pemberian kompos jerami padi plus tithonia yang dicampur dengan biochar sekam dapat meningkatkan serapan hara N,P dan K padi serta dapat meningkatkan produksi tanaman padi dengan metode SRI.

Tujuan penelitian ini adalah mengkaji dampak aplikasi kompos (jerami + tithonia) dan biochar dalam meningkatkan serapan hara N,P dan $\mathrm{K}$ padi serta dapat meningkatkan produksi tanaman padi dengan metode SRI.

\section{Bahan dan Metode}

Penelitian dilakukan di lahan sawah di Kecamatan Kuranji, Kota Padang, Sumatera Barat pada bulan November 2019 - Februari 2020. Bahan yang digunakan ialah benih padi varietas IR-42, pangkasan tanaman tithonia diversifolia segar yang diambil $50 \mathrm{~cm}$ dari pucuk, jerami padi sisa panen serta biochar yang berbahan baku dari sekam padi.

Jerami padi sisa panen dan tithonia segar yang diambil $50 \mathrm{~cm}$ dari pucuk untuk dijadikan kompos dicincang secara terpisah, lalu dilakukan pencampuran jerami padi dan tithonia dengan perbandingan yang sama (1:1) kemudian menggunakan biodekomposer dengan merk dagang EM4 yang bertujuan membantu mempercepat proses dekomposisi dan diaduk sampai homogen, kemudian di bolak-balik sekali seminggu agar suhu kompos tidak meningkat.

Proses inkubasi kompos dilakukan selama 4 bulan. Selanjutnya, tunggu sampai didapatkan kompos yang matang dengan ciri fisik ditandai dengan perubahan warna menjadi berwarna coklat tua, lunak dan mudah dihancurkan, tidak berbau menyengat, dan suhu mendekati suhu ruang $\left(25-30^{\circ} \mathrm{C}\right)$. Biochar yang berbahan baku dari sekam padi dilakukan pembakaran dengan menggunakan drum berbahan plat besi. Digunakan kayu atau batok kelapa sebagai bahan bakar dalam proses pembuatan biochar. Kayu bakar dan batok kelapa yang sudah kering lalu disiram dengan minyak tanah agar memudahkan proses pembakaran. Setelah kayu dan batok kelapa terbakar, kemudian ditutup dengan drum plat besi. Proses pembakaran sekam padi dilakukan secara tidak lansung yang mana sekam padi di letakkan di atas drum maupun di samping drum plat besi hingga alat tertutup kira-kira setengah dari tingginya. Tunggu hingga keluar asap putih dari cerobong alat. Selanjutnya, sekam padi diaduk sampai tercampur rata hingga sekam padi berubah warna menjadi hitam dan siap digunakan.

Penelitian menggunakan Rancangan Acak Kelompok (RAK) terdiri dari 6 perlakuan dan 3 ulangan dengan luas petakan masing - masing berukuran $3 \mathrm{~m} \times 1,5 \mathrm{~m}$ serta menggunakan jarak tanam $30 \mathrm{~cm} \times 30 \mathrm{~cm}$. Kombinasi perlakuan terdiri dari; $\mathrm{A}=$ kontrol, $\mathrm{B}=100 \% \mathrm{~K}$ (kompos) setara 7,50 tha-1, C=75\% K setara 5,62 tha- + $25 \% \mathrm{~B}$ (biochar) setara $1,87 \mathrm{ha}^{-1}, \mathrm{D}=50 \% \mathrm{~K}$ setara 3,75 tha-1 $+50 \%$ B setara $3,75 \mathrm{t} \mathrm{ha}^{-1}, \mathrm{E}=$ $25 \% \mathrm{~K}$ setara $1,87 \mathrm{ha}^{-1}+75 \%$ B setara 5,62 tha${ }^{1}, \mathrm{~F}=100 \%$ B setara 7,50 t ha ${ }^{-1}$. Kombinasi Kompos dan biochar diinkubasi kedalam tanah selama 15 hari sebelum tanam. Benih yang telah disemaikan pada kotak persemaian dipindahkan ke lahan sawah setelah berumur 7 - 14 hari dan sistem pengairan dalam kondisi macak - macak atau basah.

Pengamatan terhadap sifat dan ciri kimia tanah meliputi kondisi tanah sebelum perlakuan dan setelah inkubasi perlakuan. Parameter yang diamati meliputi serapan N,P dan K tanaman, jumlah anakan total dan berat gabah $\left(\mathrm{t} \mathrm{ha}^{-1}\right)$. Analisis tanaman dilakukan dengan menganalisis gabungan antara batang dan daun untuk serapan hara N, P dan $\mathrm{K}$ tanaman padi. Analisis dilakukan terhadap sampel yang telah dipanen, selanjutnya dioven selama 2 × 24 jam pada suhu $75^{\circ} \mathrm{C}$ kemudian ditimbang berat kering oven untuk menentukan serapan hara tanaman. Perhitungannya sebagai berikut : Serapan $\mathrm{N}\left(\mathrm{kg} \mathrm{ha}^{-1}\right)=(\% \mathrm{~N} \times \mathrm{BK}$ tanaman $)$; Serapan $\mathrm{P}\left(\mathrm{kg} \mathrm{ha}^{-1}\right)=(\% \mathrm{P} \times \mathrm{BK}$ tanaman $) 1$ Serapan $\mathrm{K}\left(\mathrm{kg} \mathrm{ha}^{-1}\right)=(\% \mathrm{~K} \times \mathrm{BK}$ tanaman $)$ Data yang diperoleh dianalisis dengan Annova, 


\section{Jurnal Tanah dan Sumberdaya Lahan Vol 8 No 1: 301-308, 2021}

e-ISSN:2549-9793, doi: 10.21776/ub.jts1.2021.008.1.33

dilanjutkan dengan uji DNMRT (Duncans's New

Multiple Range Test) pada taraf 5\%

\section{Hasil dan Pembahasan}

\section{Serapan N, P dan K Tanaman}

Peningkatan serapan N,P,K terbaik terjadi pada perlakuan kompos $25 \%+$ biochar $75 \%$ terhadap kontrol dengan masing-masing nilai $0,19 \% \mathrm{k}, \quad 0,05 \%$ dan $0,77 \%$. Peningkatan serapan $\mathrm{N}$ pada Tabel 1 terjadi karena input yang diberikan ke tanah berupa kompos dan biochar yang memiliki kandungan $\mathrm{N}$ yang tinggi sehingga tersedia untuk tanah dan tanaman. Hardjowigeno (2010) menyatakan bahwa N dalam tanah berasal dari bahan organik yang diberikan, pengikatan oleh mikroorganisme dan pemberian pupuk, adanya angkutan $\mathrm{N}$ yang tinggi pada daun mampu mempercepat proses fotosintesis dan mempercepat proses pembentukan organ daun. Selain itu $\mathrm{N}$ juga merupakan unsur hara yang sangat dibutuhkan oleh tanaman dalam membentuk protein dan klorofil tanaman. Kekurangan unsur hara N pada tanaman akan membuat daun menjadi lebih mudah gugur serta membuat daun menjadi berwarna kekuningan. Peningkatan serapan P (Tabel 3) terjadi akibat pemberian bahan organik disamping dapat menyumbangkan P juga menghasilkan bahanbahan terhumifikasi yang berperan untuk memperbesar ketersediaan $\mathrm{P}$ dari mineral karena membentuk P humat yang lebih mudah diserap tanaman.

Tabel 1. Serapan N, P, dan K tanaman.

\begin{tabular}{lcccc}
\hline $\begin{array}{l}\text { Kombinasi Kompos } \\
\text { (J+T) dan Biochar }\end{array}$ & $\begin{array}{c}\text { Serapan N } \\
\mathbf{( \% )}\end{array}$ & $\begin{array}{c}\text { Serapan P } \\
\mathbf{( \% )}\end{array}$ & $\begin{array}{c}\text { Serapan K } \\
\mathbf{( \% )}\end{array}$ & $\begin{array}{c}\text { Berat Kering } \\
\text { Tanaman }\left(\mathbf{k g ~ h a} \mathbf{~}^{-1}\right)\end{array}$ \\
\hline Kontrol & $0,23 \mathrm{~b}$ & $0,02 \mathrm{e}$ & $1,31 \mathrm{~b}$ & $4922,41 \mathrm{~b}$ \\
$100 \% \mathrm{~K}$ & $0,26 \mathrm{~b}$ & $0,03 \mathrm{~d}$ & $1,70 \mathrm{ab}$ & $5780,73 \mathrm{ab}$ \\
$75 \% \mathrm{~K}+25 \% \mathrm{~B}$ & $0,31 \mathrm{ab}$ & $0,04 \mathrm{c}$ & $1,62 \mathrm{ab}$ & $6612,10 \mathrm{ab}$ \\
$50 \% \mathrm{~K}+50 \% \mathrm{~B}$ & $0,34 \mathrm{ab}$ & $0,05 \mathrm{~b}$ & $2,04 \mathrm{a}$ & $6731,12 \mathrm{ab}$ \\
$25 \% \mathrm{~K}+75 \% \mathrm{~B}$ & $0,42 \mathrm{a}$ & $0,07 \mathrm{a}$ & $2,08 \mathrm{a}$ & $7147,76 \mathrm{a}$ \\
$100 \% \mathrm{~B}$ & $0,33 \mathrm{ab}$ & $0,03 \mathrm{~cd}$ & $1,67 \mathrm{ab}$ & $5519,91 \mathrm{ab}$ \\
KK & $26,42 \%$ & $10,31 \%$ & $21,35 \%$ & $19,00 \%$ \\
\hline
\end{tabular}

Angka-angka dalam kolom yang sama yang diikuti huruf kecil yang sama berbeda tidak nyata pada taraf $5 \%$ menurut DNMRT.

Sujana et al. (2014) juga menyatakan bahwa gugus fungsional diperoleh dari biochar (akibat proses pengolahan $>300^{\circ} \mathrm{C}$ ) menimbulkan partikel-partikel penyusun biochar bermuatan negatif, sehingga memiliki kemampuan yang lebih besar dalam mengikat ion-ion. $\mathrm{P}$ yang terdapat dalam biochar akan dilepas secara perlahan sehingga akhirnya $\mathrm{P}$ dapat diserap oleh tanaman.

Serapan K tanaman juga dipengaruhi oleh ketersediaan unsur $\mathrm{K}$ di dalam tanah yang juga sangat di pengaruhi oleh nilai $\mathrm{pH}$ serta KTK. Ketika nilai KTK semakin besar menyebabkan peningkatan kemampuan tanah dalam menahan kalium $\mathrm{K}$, sehingga larutan tanah lama untuk melepaskan $\mathrm{K}$ dan menurunkan potensi pencucian. Winarso (2005) juga mengemukakan bahwa $\mathrm{K}$ diserap tanaman dari tanah dalam bentuk ion $\mathrm{K}^{+}$serta berfungsi sebagai pendukung metabolisme tanaman. Unsur $\mathrm{K}$ bagi tanaman memiliki peranan penting dalam pembentukan protein dan karbohidrat, meningkatkan kualitas biji atau buah serta memperkuat batang tanaman agar daun, bunga dan buah tidak mudah rontok. Kekurangan hara $\mathrm{K}$ pada tanaman ditandai dengan adanya bercak merah kecoklatan pada daun, buah tumbuh tidak sempurna serta batang dan cabang tanaman mudah rebah (Hardjowigeno, 2010). Peningkatan serapan hara $\mathrm{N}$ dan $\mathrm{P}$ metode SRI sebagai respon terhadap aplikasi kompos $(J+T)$ dan biochar bisa disebabkan oleh kondisi rizosfer tanaman padi SRI yang cenderung aerob, sehingga menyebabkan serapan unsur-unsur hara optimal. Tanaman padi sawah tidak menghendaki kondisi anaerob pada media 


\section{Jurnal Tanah dan Sumberdaya Lahan Vol 8 No 1: 301-308, 2021 e-ISSN:2549-9793, doi: 10.21776/ub.jts1.2021.008.1.33}

pertumbuhannya, namun tanaman ini toleran terhadap kondisi anaerob tersebut. Pada kondisi jenuh air, tanaman sulit mendapatkan $\mathrm{O}^{2}$ sehingga tanaman padi menyiasatinya dengan membentuk jaringan aerenchym. Semakin lama tanaman padi tumbuh pada kondisi anaerob maka akan semakin banyak dan semakin besar jaringan aerenchym yang terbentuk. Jaringan aerenchym yang terbentuk menyebabkan terjadinya kerusakan struktur tanaman padi. Apabila jaringan aerenchym yang terbentuk semakin banyak, maka akan mengganggu proses penyerapan hara dan air oleh akar tanaman (Sumardi, 2007). Berat kering tanaman terlihat memberikan peningkatan terbaik pada perlakuan $25 \% \mathrm{~K}+75 \% \mathrm{~B}$ terhadap kontrol sebesar 2225,35 kg ha-1 (Tabel 1). Di indikasikan dengan pemberian perlakuan dan sistem budidaya padi SRI memberikan jumlah anakan yang banyak sehingga mempengaruhi berat kering tanaman. Hal ini sependapat dengan
Usman et al. (2014) yang menyatakan bahwa peningkatan berat kering tanaman disebabkan oleh jumlah anakan yang banyak dan morfologi tanaman yang lebih tinggi.

\section{Tinggi tanaman}

Pengaruh aplikasi kombinasi kompos dan biochar terhadap tinggi tanaman tidak berbeda nyata pada perlakuan $50 \% \mathrm{~K}+50 \% \mathrm{~K}$ dengan $25 \% \mathrm{~K}+75 \%$ B (Gambar 1). Namun peningkatan tertinggi terjadi pada perlakuan $25 \%$ $\mathrm{K}+75 \% \mathrm{~B}$ dan lebih baik dibandingkan dengan tanpa perlakuan yaitu $78,67 \mathrm{~cm}$ menjadi 108,67 $\mathrm{cm}$. Dapat dikatakan bahwa bahan organik berupa kompos dan biochar merupakan sumber unsur hara bagi tanaman sehingga menunjang pertumbuhan tanaman. Menurut Purbajanti et al. (2019) bahan organik dapat memperbaiki struktur tanah dan sekaligus meningkatkan ketersediaan sumber hara serta berkontribusi pada pertumbuhan dan hasil tanaman.

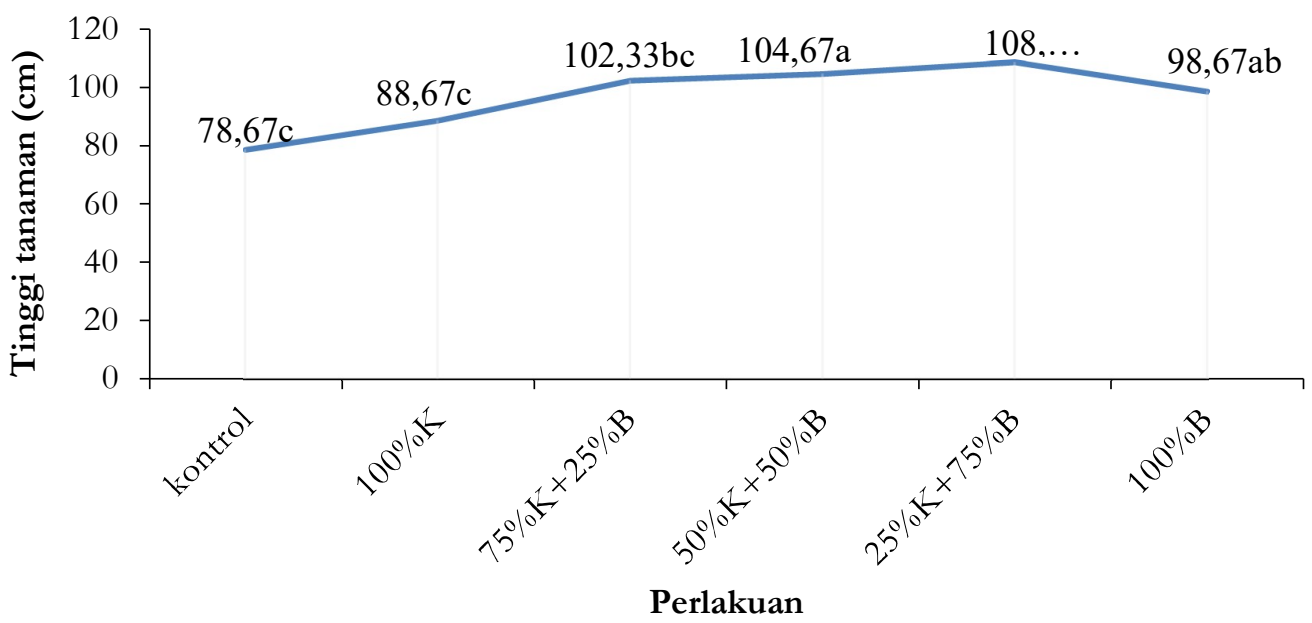

Gambar 1. Tinggi tanaman dengan beberapa kombinasi perlakuan pada umur 70 HST.

\section{Jumlah anakan total}

Gambar 2 menunjukkan bahwa jumlah anakan total terbaik terjadi pada perlakuan kompos $25 \%$ + biochar 75\% terhadap kontrol (27,66 menjadi $53,00)$. Hal ini terjadi karena peran kompos dan biochar sebagai penyedia nutrisi hara sehingga meningkatkan pertumbuhan vegetatif tanaman. Ningtias dan Suharjanto (2012) menyatakan bahwa pemanfaatan jerami padi pada penerapan
SRI Aerob Terkendali Berbasis Organik (IPATBO) dapat memperbaiki kesuburan tanah dengan meningkatkan pertumbuhan tanaman misalnya tinggi tanaman, jumlah anakan, dan hasil panen sebesar 9,10 $\mathrm{t} \mathrm{ha}^{-1}$. Demikian juga dilaporkan oleh Kaya (2018), bahwa pemberian kompos jerami padi dapat meningkatkan serapan N, tinggi tanaman, dan jumlah anakan. Salah satu unsur hara yang mengaruhi jumlah anakan adalah unsur P. 


\section{Jurnal Tanah dan Sumberdaya Lahan Vol 8 No 1: 301-308, 2021 e-ISSN:2549-9793, doi: 10.21776/ub.jts1.2021.008.1.33}

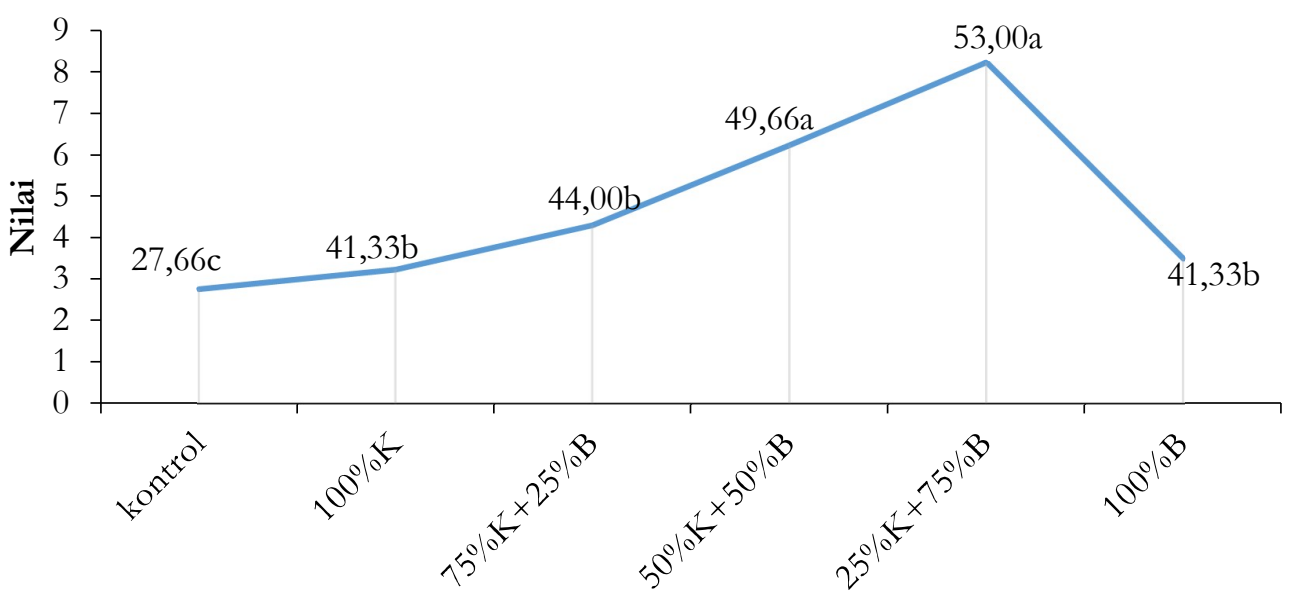

Perlakuan

Gambar 2. Jumlah anakan total dengan beberapa kondisi perlakuan.

Harran (1975) menyatakan bahwa unsur P yang diserap tanaman berperan dalam aktivitas pembelahan sel. Pembentukan sel akan membantu pembentukan anakan padi, maka dengan semakin meningkatnya penyerapan $\mathrm{P}$ oleh tanaman akan meningkatkan jumlah anakan padi. Deptan Badan Pengendali Bimas Jakarta (1977) Jumlah anakan maksimum/rumpun dapat digolongkan: sangat rendah ( $<5$ batang), rendah (5-8 batang), sedang (9-12 batang), tinggi (13-16 batang) dan sangat tinggi (>16 batang). Untuk varietas yang ditanam yaitu IR 42 termasuk kedalam kategori sangat tinggi karena lebih dari 16 batang dan biasanya dengan SRI bisa mencapai $>50$. Selain itu banyaknya anakan maksimum dipengaruhi oleh jarak tanam dengan metode SRI yang lebih lebar dan pola tanam 1 batang dalam lubang tanam. Jumlah anakan pada metode SRI lebih banyak karena bibit yang ditanam adalah umur muda (8 hari) setelah sebar, menanam 1 bibit dalam 1 lubang dan kondisi ini menstimulir terbentuknya anakan yang banyak. Kondisi tanah yang tidak tergenang menyebabkan aerase disekitar perakaran sangat memungkinkan phyllochron dari tanaman padi untuk berkembang (terus membentuk anakan).

\section{Berat gabah}

Peningkatan terbaik ditunjukkan pada perlakuan 25\% K + 75\% B (Gambar 3).
Meningkatnya berat gabah dipengaruhi oleh faktor-faktor khusus seperti; jumlah anakan produktif per rumpun, persentase gabah isi dan bobot 1000 biji. Meningkatnya faktor-faktor tersebut didukung oleh ketersediaan unsurunsur hara yang diperlukan dalam setiap proses pertumbuhan dan perkembangan secara optimal dan kondisi fisik, kimia, dan biologi tanah yang memadai. Ketersediaan unsur nitrogen memegang peranan yang sangat penting dalam produksi tanaman padi. Hal ini sesuai dengan kandungan $\mathrm{N}$ yang tinggi pada kompos serta peran biochar dalam mempertahankan nitrogen dan luas permukaan yang besar sehingga dapat meningkatkan nitrogen tanah. Menurut Soegiman (1982), tanaman padi-padian, nitrogen yang cukup akan memperbanyak dan memperbesar butiran biji padi sehingga akan meningkatkan hasil tanaman. Barkelaar (2001) menyatakan bahwa metode SRI minimal menghasilkan panen 2 kali lipat dibandingkan metode konvensional karena telah terbukti di Madagaskar di mana pada beberapa tanah tidak subur yang produksi normalnya $2 \mathrm{t} \mathrm{ha}^{-1}$ dapat meningkat menjadi lebih dari $8 \mathrm{t} \mathrm{ha}^{-1}$ bahkan ada yang mencapai 20 t ha ${ }^{-1}$. Produksi padi dengan metode SRI sangat baik yaitu berkisar antara 7,5 - 10,6 ton GKP (Nururudin, dkk. 2000). Rata-rata hasil metode SRI di 12 negara di Asia, Amerika dan Afrika, menunjukkan hasil padi 7,0 t ha-1 berbanding 


\section{Jurnal Tanah dan Sumberdaya Lahan Vol 8 No 1: 301-308, 2021 e-ISSN:2549-9793, doi: 10.21776/ub.jts1.2021.008.1.33}

metode konvensional 3,9 t ha-1 (Uphoff, 2004). Hasil padi dengan metode SRI di berbagai lokasi lainnya antara lain di Srilanka $13 \mathrm{t} \mathrm{ha}^{-1}$ dengan penghematan air 40-50\%, di Kuba 14 t $\mathrm{ha}^{-1}$ (varietas Los Palacios 9), Indonesia (Timor Barat-NT') hasil panen cara biasa 4,4 $\mathrm{t} \mathrm{ha}^{-1}$, cara SRI 11,7 t ha-1, Peru cara biasa $2 \mathrm{t} \mathrm{ha}^{-1}$, cara SRI $8 \mathrm{t} \mathrm{ha}^{-1}$ (Uphoff, 2004).

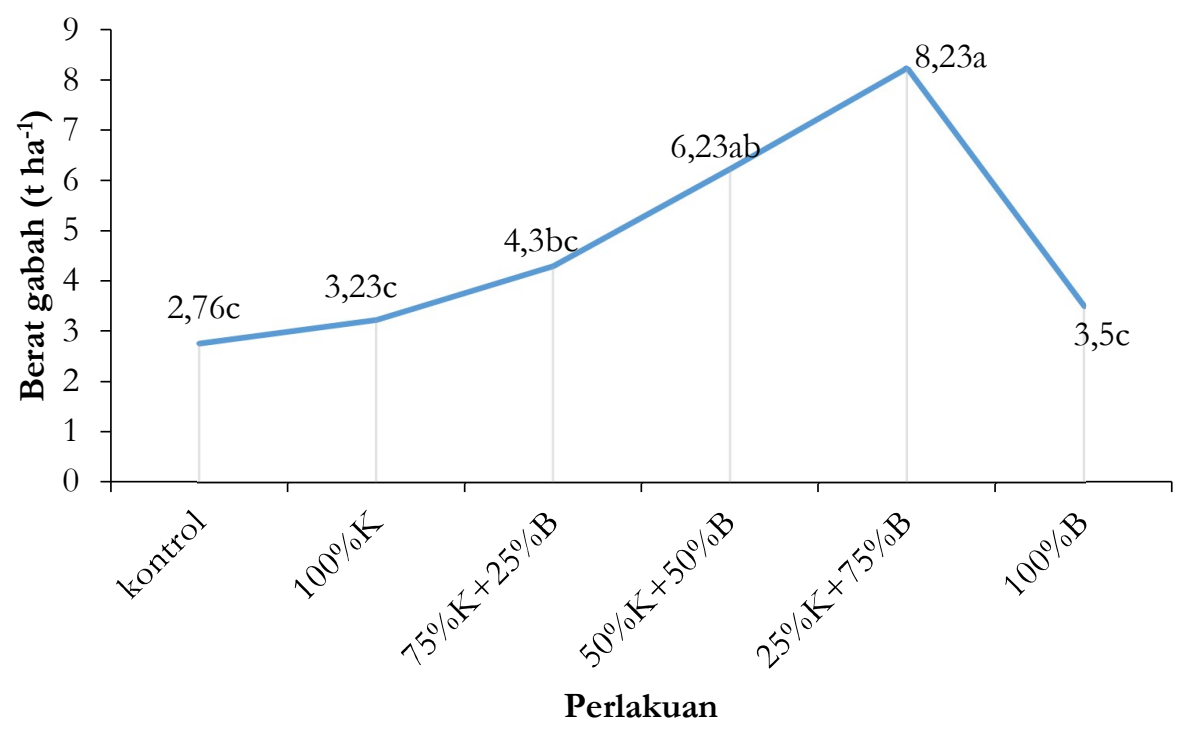

Gambar 3. Hasil gabah per petak dan per hektare dengan beberapa kombinasi perlakuan.

\section{Kesimpulan}

Aplikasi kompos (jerami+tithonia) dan biochar mampu meningkatkan serapan hara N, P dan K padi metode SRI (System of Rice Intensification) pada perlakuan kompos $25 \%+$ biochar $75 \%$. Peningkatan tinggi tanaman, jumlah anakan total dan berat gabah per hektare terbaik terjadi pada perlakuan kompos $25 \%+$ biochar $75 \%$ masing-masing dengan nilai $30 \mathrm{~cm}, 25,34$ batang dan 5,47 t ha ${ }^{-1}$ terhadap kontrol.

\section{Daftar Pustaka}

Barkelaar, D. 2001. EDN Stories: SRI, The System of Rice Intensification: Less Can be More.

BPS (Badan Pusat Statistik). 2017. produksi padi di Sumatera Barat. www.bps.co.id.

Departemen Pertanian Badan Pengendali Bimas. 1977. Pedoman Bercocok Tanam Padi, Palawija dan Sayur - sayuran. Jakarta (ID): Departemen Pertanian Badan Pengendali Bimas.

Djinis, Musdar, E., Sorel, D., Ismawardi, Elita, N., Sondang, Y. dan Ukrita, I. 2008. Penyuluhan dan Pembuatan Demontrasi Plot Penanaman Padi
Metode The System of Rice Intensification (SRI). Journal Penelitian Lumbung 7(1):28-35.

Feng, Y.C., Jun, M., Xiang, W.Q., Ming, Z.W., Yi, C.Y. and Fu, C.W. 2017. Effects of straw and biochar addition on soil nitrogen, carbon, and super rice yield in cold waterlogged paddy soils of North China. Journal of Integrative Agriculture 16(5): 1064-1074.

Gusnidar, Fania, U. dan Gusmini. 2017. Tithonia dan Jerami Padi yang Dikomposkan Untuk Perbaikan Ciri Kimia Oxisol dan Produksi Cabay Kopay. Dalam Prosiding Seminar Nasional Lahan Sub Optimal, 19-20 Oktober 2017. Hal1926.

Gusnidar, Fitri, A. dan Yasin, S. 2019. Tithonia dan jerami padi yang dikomposkan terhadap ciri kimia tanah dan produksi jagung pada Ultisol. Jurnal Solum XVI(1): 11-18.

Gusnidar, Yasin, S. dan Burbey. 2008. Pemanfaatan Gulma Tithonia Diversifolia dan Jerami SebagaiBahan Organik In Situ Untuk Mengurangi Penggunaan Pupuk Buatan Serta Meningkatkan Hasil Padi Sawah Intensifikasi. Laporan Hasil Penelitian KKP3T. Kerja Sama Unand-Litbang Pertanian. 49 hal. 


\section{Jurnal Tanah dan Sumberdaya Lahan Vol 8 No 1: 301-308, 2021 e-ISSN:2549-9793, doi: 10.21776/ub.jts1.2021.008.1.33}

Gusnidar, Yasin, S., Burbey dan Resi. 2011. Aplikasi kompos titonia dan jerami terhadap pengurangan input pupuk buatan dan pengaruhnya terhadap produksi padi. Jurnal Solum VIII(1): 19-26.

Hardjowigeno, S. 2010. Ilmu Tanah. Akademika Pressindo. Jakarta.

Harran S. 1975. Fisiologi Tanaman Padi. Bogor (ID): Fakultas Pertanian Institut Pertanian Bogor.

Jama, B., Palm, C.A., Buresh, R.J., Niang, A. and Gachengo, C. 2000. Tithonia diversifolia as a green manure for soil fertility improvement in Western Kenya: a review. Agroforestry System 49:201221.

Kaya. E. 2018. Pengaruh kompos jerami dan pupuk NPK terhadap N-tersedia tanah, serapan-N, pertumbuhan dan hasil padi sawah (Oryza sativa L). Agrologia 2(1): 43-50.

Kompas, edisi Rabu 16 Januari 2008. Dipopulerkan, Penanaman Padi Sebatang. http:/ /www.kompascetak.com/kompascetak/0 801/16/sumbagut/4168753.htm.

Lehmann, J. and Joseph, S. 2009. Biochar for EnvironmentalManagement: Science and Technology. Earthscan-UK.p, 71-78.

Ningtias, E.M.N. dan Suharjanto, T. 2012. Sistem intensifikasi padi aerob terkendali berbasis organik di Kelurahan Tunggul Wulung Kota Malang. Agrika 6(1): 13-21.

Nurudin, Bunyamin, Eman, Heri, Omod, Suardi, Mastur, Samiri, Dede Laso,Tohirin, Maman, Sanmuhilal, Tawud, Saeun, Juri, A. Humroni, Maman, Musim, Undang H, Birin, Oen, Udin, Engkus, Dadang dan Keni. 2000. Pengalaman KSP Bumi Sejati dalam Bertanam Padi Metode SRI (System of Rice Intensification). Kelompok Studi Petani Bumi Sejati/P3A Mekar Jaya. Ciamis, Jawa Barat.

Prasetiya, A., Lisa, M. dan Jonatan, G. 2015. Respon bawang merah (Allium ascalonicum L.) varietas Medan pada tanah terkena vulkanik dengan pemberian bahan organik. Jurnal Online Agroekoteknologi 3(2): 476-482.
Purbajanti. E.D., Slamet, W., Fuskhah, E. and Rosyida. 2019. Effects of organic and inorganic fertilizers on growth, activity of nitrate reductase and chlorophyll contents of peanuts (Arachis bypogaea L.). IOP Conf. Series: Earth and Environmental Science 250.

Randriamiharisoa, R.P. 2002. Research Result on Biological Nitrogen Fixation with the System of Rice Intensification. Proceedings International Conference Assessments of System of Rice Intensification, Uphoff, N., Fernandes, E.C.M., Editor, Sanya, CIIFAD, 40-46.

Soegiman. 1982. Ilmu Tanah. Terjemahan dari The Nature and Properties of Soils oleh Buckman and Brady. Barata Karya Aksara. Jakarta. 788 hal.

Sujana. I.P., Suryana, I.M. dan Suyasdipura, I.N.L. 2014. Perbaikan sifat fisik dan kimia tanah sawah tadah hujan melalui pemberian biochar dalam upaya meningkatkan produktivitas lahan. Agrimeta 4(8).

Sumardi. 2007. Respon padi sawah pada teknik budidaya secara aerobik dan pemberian bahan organik. Akta Agrosia 10: 65-70.

Uphoff, N. 2004. The System of Rice Intensification (SRI): An Opportunity for Raising Productivity in the 21st Century, International Rice Conference. FAO, Rome Feb. 12- 13, 2004. CIIFAD - Cornell University, USA.

Usman. Z., Made, U. dan Adrianton. 2014. Pertumbuhan dan hasil tanaman padi (Oryza sativa L.) pada berbagai umur semai dengan teknik budidaya SRI (System of Rice Intensification). Jurnal Agrotekbis 2(1) : 32-37.

Winarso, S. 2005. Kesuburan tanah Dasar Kesehatan dan Kualitas Tanah.Gava Media Yogyakarta.

Yasin, S., Hidayat, S., Iko, M., Darfis. I. dan Gusnidar .2017. Pengaruh Komposisi Kompos Biochar dan kapur terhadap Perbaikan Kesuburan Tanah Inceptisol dan Pertumbuhan Tanaman kopi di Alahan Panjang. Laporan Penelitian. Fak. Pertanian Univ. Andalas Padang. 